\title{
The design of slow sand filter with a media of silica sand and granular activated carbon to eliminate iron, manganese, and fecal coliform contents for the Faculty of Nursing in Universitas Indonesia's CWPS
}

\author{
Adrian Wasistoadi Budiarto ${ }^{1}$, Fairuz Tsania ${ }^{1}$, Irma Gusniani $^{2}$, and Djoko M. Hartono ${ }^{2 *}$ \\ ${ }^{1}$ Faculty of Engineering, Universitas Indonesia, Depok, 16424, Indonesia. \\ ${ }^{2}$ Department of Civil Engineering, Universitas Indonesia, Depok, 16424, Indonesia.
}

\begin{abstract}
The Faculty of Nursing of Universitas Indonesia in Depok uses groundwater as the source of clean water in a large amount: 2.115 .240 liters in 2018 and 22.010.960 liters in 2019. One of the alternatives for reducing groundwater use is to utilize surface water in the surrounding area of the campus, such as Lake Agathis. For the lake water to be used as the source of clean water, it needs to be processed first using a clean water provision system (CWPS). The CWPS is designed to contain two slow sand filter units, with the media consisting of $60 \mathrm{~cm}$-thick silica sand and $40 \mathrm{~cm}$-thick granular activated carbon in each unit. The CWPS is also equipped with one unit of shore intake, two units of suction well, one transmission duct, one unit of disinfectant and reservoir, and two filter media cleaning units. Based on a literature review from several journals and the results from this experiment, the designed slow sand filter with the previously determined thickness can reduce iron contents by $95,07 \%$, manganese contents by $97,09 \%$, and fecal coliform contents by $99 \%$. The designed CWPS can serve the needs of clean water of the faculty described before with a debit of 3,8 $\mathrm{L} / \mathrm{s}$ until the year 2042 .
\end{abstract}

\section{Introduction}

Water is an element that has an essential role in ensuring the sustainability of almost all living things in this world, which is used to meet the daily needs of humans, such as for drinking, for washing, for cooking, for bathing, and so on. Clean water also has a vital role in education, such as in universities. Apart from being used for drinking and sanitation needs for students and lecturers, clean water is used for learning and experiments in laboratories for students in individual faculties, such as the engineering, natural sciences, and health faculties. Thus, the provision of clean water becomes the university's responsibility so that all activities, both teaching and learning and other activities carried out by students, lecturers, and the staff, can run well.

\footnotetext{
* Corresponding author: djokomh@eng.ui.ac.id
} 
As one of the best universities in Indonesia, Universitas Indonesia is responsible for the provision of clean water for all activities within the university and the regulation of how the water provided can be efficiently used and reused. This is because Universitas Indonesia has implemented a green and sustainable campus program since 2010. The program is known as UI GreenMetric, which has been regulated in the Decree of the Rector of the Universitas Indonesia Number 2893/SK/R/UI/2018 concerning Universitas Indonesia's Green Campus Policy.

One of the faculties at the University of Indonesia, namely the Faculty of Nursing UI (FIK UI), is known still to use groundwater as its sole source of clean water. Based on information obtained from the FIK UI Education and Laboratory Building Facility Coordinator as stated by the Research-Publications-Public Service Division of FIK UI, the use of the buildings groundwater during 2018 and 2019 was quite massive, being 2,115,240 liters and 2,010,960 liters respectively, not using any water from the Local Drinking Water Company in those years. Because groundwater availability is not always abundant, FIK UI needs to find alternative clean water sources, one of which is by using surface water from Lake Agathis. Lake Agathis has several parameters that do not meet quality standards, iron, manganese, and fecal coliform levels. According to measurements carried out by the UI Engineering Lab, the amount of iron in the inlet of Lake Agathis is $2.31 \mathrm{mg} / \mathrm{L}$, which exceeds the maximum limit of iron levels according to the Regulation of the Minister of Health of the Republic of Indonesia No. 492/2010 concerning the Requirements for the Quality of Drinking Water, which is $0.3 \mathrm{mg} / \mathrm{L} \mathrm{[1]}$. Based on the same source, the manganese and fecal coliform levels of the lake was $0.51 \mathrm{mg} / \mathrm{L}$ and $34 \mathrm{MPN} / 100 \mathrm{~mL}$, respectively, both of which exceeded the maximum levels of manganese and fecal coliforms according to Regulation of the Minister of Health of the Republic of Indonesia No. 492/2010 of $0.4 \mathrm{mg} / \mathrm{L}$ and 0 MPN/100 mL respectively. Therefore, water from Lake Agathis must be treated first before becoming a source of clean water for FIK UI.

There are various kinds of water treatment methods that can be used to process raw water from its source into clean water ready to use, one of which is filtration. The medium commonly used for infiltration is sand. Filters with sand as its medium are a reasonably simple filtration technology, are cheap to manufacture and maintain and are easy to operate [2]. One type of filter with sand as its medium based on its filtering speed is a slow sand filter, a filter with a filtering speed of 20 to 50 times slower than a rapid sand filter [3]. A slow sand filter is the right type to use in eliminating pathogenic bacteria, one of which is coliform bacteria. The efficiency of removing these bacteria on a slow sand filter can reach $99 \%$, depending on the factors that influence it, such as medium thickness and filtration rate [4]. Slow sand filters can be the right treatment option to process Lake Agathis's water into clean water suitable for consumption.

This research is a process of designing a CWPS with a slow sand filter unit, which is projected to serve FIK UI until 2042. The slow sand filter has two types of media, namely silica sand and granular activated carbon (GAC), which are known to be able to remove an iron level, manganese level, and fecal coliform as the main parameters according to Regulation of the Minister of Health of the Republic of Indonesia No. 492/2010 concerning the Requirements for the Quality of Drinking Water.

\section{Method}

The CWPS, which will be designed, focuses on the slow sand filter unit. Design and projections refer to the estimated construction time starting in 2021, starting operations in 2022, and will serve FIK UI until 2042. So, the CWPS will be assumed to operate normally for 20 years. 


\subsection{Literature study of iron, manganese, and fecal coliform removal in the design of slow sand filter}

Several journals, articles, and experimental results related to slow sand filters that use silica sand and GAC as media will be used to conclude the efficiency of removing iron, manganese, and fecal coliform in the slow sand filter designed in this study. From the literature, the thickness of silica sand and GAC will be determined, as well as the removal efficiency of the three parameters of focus. The following are the literature used:

- Analisis Efektivitas Intermittent Slow Sand Filter dengan Tambahan Media Karbon Aktif untuk Menghilangkan Kandungan Besi, Mangan, Kekeruhan, dan Fekal Koliform [5]

- Greywater Treatment Using GAC Biofilm Reactor and Sand Filter System [6]

- Pengaruh Penggunaan Media Filtrasi Terhadap Kualitas Air Sumur Gali Di Kelurahan Tambak Rejo Waru Kabupaten Sidoarjo [7]

- Penggunaan Bahan Alam Zeolit, Pasir Silika, dan Arang Aktif dengan Kombinasi Teknik Shower dalam Filterisasi Fe, Mn, dan Mg pada Air Tanah di UPN Veteran Yogyakarta [8]

- Pengaruh Variasi Ketebalan Pasir Dan Karbon Aktif Pada Media Saringan Pasir Lambat Terhadap Penurunan Kadar Besi (Fe) Dan Mangan (Mn) Pada Air Sumur [9]

- Pengaruh Aerasi Bertingkat Dengan Kombinasi Saringan Pasir, Karbon Aktif, Dan Zeolit Dalam Menyisihkan Parameter Fe Dan Mn Dari Air Tanah Di Pesantren ArRaudhatul Hasanah [10]

- Pemanfaatan Zeolit dan Karbon Aktif dalam Menurunkan Jumlah Bakteri pada Filter Pengolah Air Payau [11]

- Pengaruh Tinggi Unggun Karbon Aktif dan Pasir Kuarsa Pada Saringan Pasir Lambat Untuk Penyisihan Logam Fe Pada Air Sungai Siak [12]

\subsection{Design and calculation}

\subsubsection{Projection of the number of FIK UI community members}

The projection of the number of FIK UI community members, consisting of students, lecturers, and educational staff, refers to the actual data on the number of FIK UI members in 2014-2019. Projections will be carried out using three methods, namely arithmetic, geometric, and linear regression methods.

- Arithmetic Method

$$
\begin{gathered}
P_{n}=P_{0}+K_{a}\left(T_{n}+T_{0}\right) \\
K_{a}=\frac{\left(P_{n}-P_{0}\right)}{\left(T_{n}-T_{0}\right)}
\end{gathered}
$$

Notes:

$P_{n}=$ number of community members in year $\mathrm{n}$, measured in lives.

$P_{0}=$ number of community members in year 0 or at the beginning of the design, measured in lives.

$K_{a}=$ community population growth constant

$T_{n}=$ year $\mathrm{n}$

$T_{0}=$ year 0 or the beginning of the design

- Geometric Method 


$$
\begin{gathered}
P_{n}=P_{0}(1+r)^{n} \\
r=\left(\frac{P_{n}}{P_{0}}\right)^{\frac{1}{N}}-1
\end{gathered}
$$

Notes:

$P_{n}=$ number of community members in year $\mathrm{n}$, measured in lives.

$P_{0}=$ number of community members in year 0 or at the beginning of the design, measured in lives.

$n=$ duration or year

$r=$ average yearly growth of the number of community members

$\mathrm{N}=$ difference in years with year 0

- Linear Regression Method

$$
\begin{gathered}
P=a+b x \\
a=\frac{\sum P \sum x^{2}-\sum x \sum P x}{N \sum x^{2}-\left(\sum x\right)^{2}} \\
b=\frac{N \sum P x-\sum x \sum P}{N \sum x^{2}-\left(\sum x\right)^{2}}
\end{gathered}
$$

Notes:

$a \& b \quad=$ constants

$P \quad=$ targeted number of community members

$x \quad=$ value taken from independent variable

$N \quad=$ number of data owned

From the projection results of the three methods, the projection method with the lowest standard deviation and an R-value closest to 1 is chosen, which indicates that the projection of the number of people with years is getting stronger or has a correlation [13].

\subsubsection{Projection of clean water needs for FIK UI.}

After projecting the number of community members, the projection results will be multiplied by the standard of clean water needs from SNI 03-7065-2005 regarding the Plumbing System Planning Procedures. Referring to this regulation, FIK UI is included in building use of facilities for high schools and higher, with a water use standard of 80 liters/student/day. The need for clean water that has been obtained by multiplying the projected number of populations with these standards is multiplied again by a factor of $1.15-1.2$ as the maximum need for clean water [14].

\subsubsection{Determination of the components and units of Water Treatment Plant (WTP)}

In this step, the units used in the designed WTP as a complement to the slow sand filter will be determined. The units' determination is based on the physical, chemical, and biological characteristics of the raw water, which will then be adjusted to national and international standards regarding WTP and slow sand filter design. The standards that will be used for this step are:

- Spesifikasi Unit Paket Instalasi Pengolahan Air by Pusat Penelitian dan Pengembangan Permukiman Balitbang Kementerian Pekerjaan Umum (2014) [15] 
- Technical Guidelines for the Construction and Management of Slow Sand Filters by Public Water Corporation MIWR-GONU (Ministry of Irrigation and Water Resources - Government of National Unity) and MWRI-GOSS (Ministry of Water Resources and Irrigation - Government of Southern Sudan) supported by UNICEF (2007) [16]

- Water Treatment Manuals Filtration by EPA (1995) [17]

- Modul Sosialisasi dan Diseminasi Standard Pedoman dan Manual dari Instalasi Saringan Pasir Lambat by Balitbang PUPR (2014) [18]

\subsubsection{Determination of the location of the WTP}

The determination of the designed WTP location in this research will be done using the Google Earth Pro application. The determination of a good location for the WTP considers the following [19]:

- The WTP is not located far from the intake point.

- The WTP is not located far from the service destination.

- The WTP is close to or has access to the main street.

- The land the WTP is on is large enough for possible expansions or an increase in WTP Capacity.

- The WTP and intake point is located far enough from human and animal activities, with a minimum distance of 65 meters.

- The location of the WTP is not historical or archaeological.

\subsubsection{Design calculations for the WTP units}

The calculation of the design of the WTP units that have been determined refers to the calculation steps and design criteria from the books Water and Waste Water Engineering [20], Water Works Engineering [21], Specifications for Water Treatment Installation Package Unit by PUPR 2014, and SNI 6774: 2008.

\subsection{Shop drawings}

Shop drawings will be made using AutoCAD. For each unit, at least one shop drawing for the top view and side view and additional necessary details, will be made. Moreover, the overall layout of the WTP will also be drawn.

\section{Results and discussion}

\subsection{Conclusions from literature Review regarding the Efficiency of Iron, Manganese, and Fecal Coliform Removal for the Design of Slow Sand Filter}

7 DEQID

\begin{tabular}{|c|c|c|c|}
\hline \multicolumn{1}{|c|}{ PARAMETER } & VALUE & UNIT & REFERENCE \\
\hline Parameter removal Efficiency: & & & \\
$\circ \quad$ Iron & 95,07 & $\%$ & {$[9]$} \\
$\circ \quad$ Manganese & 97,09 & $\%$ & {$[9]$} \\
$\circ \quad$ Fecal Coliform & 99 & $\%$ & {$[5]$} \\
\hline Media composition stated in thickness (top to bottom): & & & \\
$\circ \quad$ Silica Sand & 60 & $\mathrm{~cm}$ & {$[9]$} \\
$\circ \quad$ Activated Carbon & 40 & $\mathrm{~cm}$ & {$[9]$} \\
\hline
\end{tabular}


Based on the literature reviewed, it can be concluded that with $60 \mathrm{~cm}$ of silica sand and 40 $\mathrm{cm}$ of granular activated carbon or GAC, the slow sand filter designed is estimated to be able to remove iron with an efficiency of $95.07 \%$, manganese by $97.09 \%$, and fecal coliform by $99 \%$.

\subsection{Design calculations and shop drawings}

\subsubsection{Projection of the Number of FIK UI Community Members}

The projection results for the growth in the number of FIK UI students using the arithmetic method have the lowest standard deviation value $(52,69)$ and the correlation coefficient closest to $1(0,261)$. Meanwhile, for the projection of the number of staff (lecturers and educational staff) of FIK UI, the arithmetic method has the lowest standard deviation value $(2,5)$ and the correlation coefficient closest to $1(0,787)$. Therefore, the projection method that will be used is the arithmetic method.

Table 2. 2022-2042 Projection Results for the Number of FIK UI Community Members using Arithmetic Method. (source: author's analysis, 2020)

\begin{tabular}{|c|c|c|c|}
\hline \multicolumn{5}{|c|}{ TOTAL PROJECTION OF FIK UI COMMUNITY MEMBERS } \\
\hline YEAR & STUDENTS & STAFF & TOTAL \\
\hline 2022 & 1456 & 144 & 1599 \\
\hline 2027 & 1596 & 156 & 1752 \\
\hline 2032 & 1737 & 169 & 1906 \\
\hline 2037 & 1878 & 181 & 2059 \\
\hline 2042 & 2019 & 194 & 2212 \\
\hline
\end{tabular}

\subsubsection{Projection of Clean Water Needs for FIK UI}

Assuming that there is an increase in the standard of clean water needs from time to time, for the year 202280 liters/student/day as stated in SNI 03-7065-2005 will be used and for 2042, it will be 100 liters/student/day. In addition to the need for clean water for consumption, the need for water for the laboratory will be considered because FIK UI has laboratories and experimental rooms in the FIK UI Education \& Laboratory building. The amount of clean water needed for the laboratory is assumed to be $10 \%$ of the community's total clean water necessities. The amount of clean water needed that has been obtained by multiplying the projected number of populations with the standards mentioned in the previous section is multiplied again by a factor of 1,2 as the maximum daily water necessity [14]. The total demand for clean water at peak hours will be added to the installation flow rate to obtain the design discharge. Installation discharge is an additional discharge to prevent overload or overflow during the operation of the WTP. It is assumed to be $10 \%$ of the maximum daily clean water necessity [21].

Table 3. 2022-2042 Total Clean Water Needs Projection for FIK UI (source: author's analysis, 2020) 


\begin{tabular}{|c|c|c|c|c|c|}
\hline \multirow{2}{*}{ YEAR } & TOTAL & $\begin{array}{c}\text { STANDARD } \\
\text { CLEAN } \\
\text { WATER } \\
\text { NEEDS }\end{array}$ & $\begin{array}{c}\text { COMMUNITY } \\
\text { CLEAN } \\
\text { WATER } \\
\text { NEEDS }\end{array}$ & $\begin{array}{c}\text { LABORATORY } \\
\text { WATER } \\
\text { NEEDS }\end{array}$ & $\begin{array}{c}\text { TOTAL } \\
\text { CLEAN } \\
\text { WATER } \\
\text { NEEDS }\end{array}$ \\
\cline { 2 - 6 } & Lives & L/life/day & L/day & L/day & L/second \\
\hline 2022 & 1599 & 80 & 127920 & 12792 & 1.63 \\
\hline 2042 & 2212 & 100 & 221233 & 22123 & 2.82 \\
\hline
\end{tabular}

Table 4. 2022-2042 Designed WTP debit projection for FIK UI (source: author's analysis, 2020)

\begin{tabular}{|c|c|c|c|c|c|}
\hline \multirow{3}{*}{ YEAR } & $\begin{array}{c}\text { TOTAL } \\
\text { CLEAN } \\
\text { WATER } \\
\text { NEEDS }\end{array}$ & $\begin{array}{c}\text { MAXIMUM } \\
\text { FACTOR }\end{array}$ & $\begin{array}{c}\text { MAILY } \\
\text { MAXIMUM } \\
\text { CLEAN } \\
\text { WATER } \\
\text { NEEDS }\end{array}$ & $\begin{array}{c}\text { INSTALLED } \\
\text { DEBIT }\end{array}$ & $\begin{array}{c}\text { DESIGNED } \\
\text { DEBIT }\end{array}$ \\
\cline { 2 - 4 } & L/second & & L/second & L/second & L/detik \\
\hline 2022 & 1.63 & 1.2 & 1.95 & 0.20 & 2.15 \\
\hline 2042 & 2.82 & 1.2 & 3.38 & 0.34 & 3.8 \\
\hline
\end{tabular}

\subsubsection{Determination of WTP units}

It has been concluded that in the WTP for FIK UI, the slow sand filter unit does not require chemical pre-treatment and in fact, raw water from the intake can be directly channeled to the filter unit [17]. Therefore, the proposed WTP unit flow is as follows:

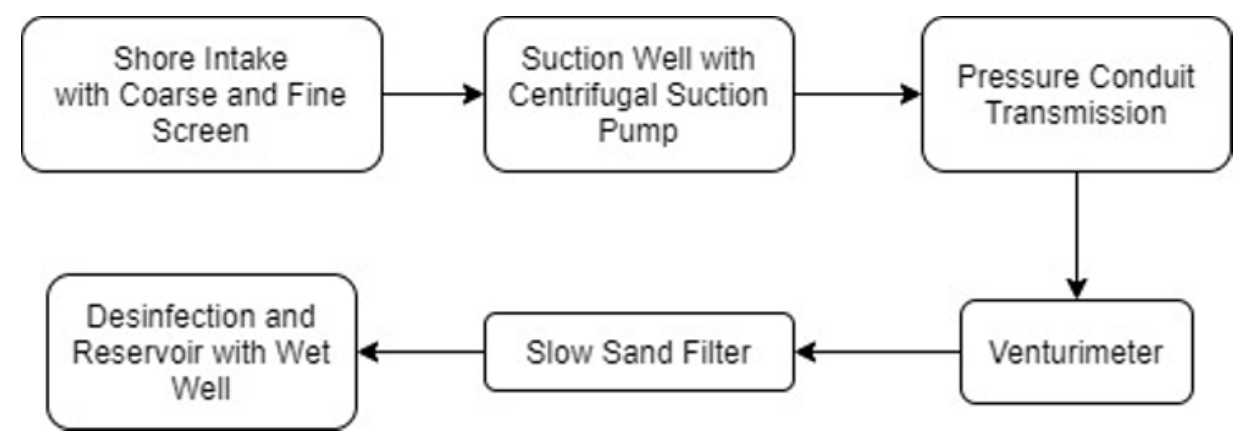

Fig 1. The chosen and implemented WTP unit flow chart. 


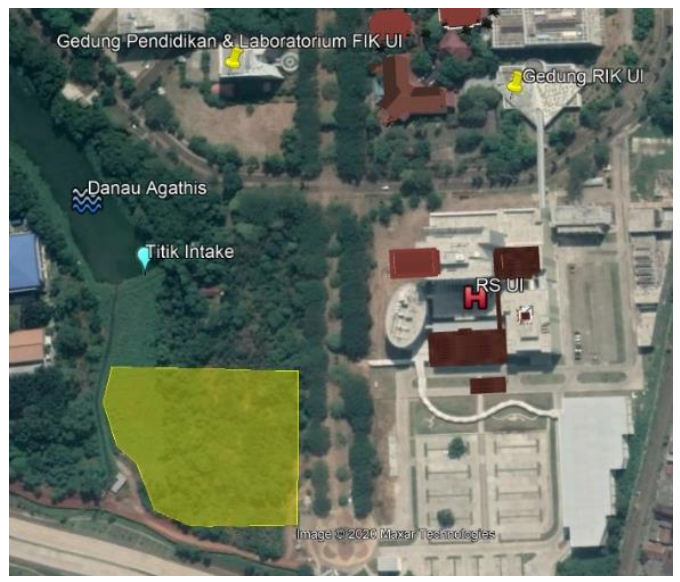

Fig 2. Planned location for the construction of the designed WTP

\subsubsection{Determination of the location of the WTP}

The development of the designed WTP for FIK UI is marked with a slightly transparent yellow area in the image above in Figure 2. This location has an area of approximately 16300 $\mathrm{m}^{2}$. This location is chosen because it is considered close to the raw water source and the service destination. The location is approximately 75 meters from Lake Agathis and 206 meters from the FIK UI Education \& Laboratory Building. This location is surrounded by the PNJ campus building, UI Hospital, and Depok-Antasari Toll Road. The intake point is 81 meters from the nearest building, namely the PNJ campus, and is 285 meters from the nearest housing complex, Beji Timur. The elevation of the land at this location is in the range of 70-72 masl.

\subsubsection{Calculations and shop drawings for the WTP units}

\section{Shore Intake}

One shore intake unit is designed with a unit depth of 2 meters, a water gate height of 1,5 meters, and a water gate width of 1 meter. There is one coarse screen $(2 \mathrm{~cm}$ space between bars) and one piece of fine screen $(0,5 \mathrm{~cm}$ space between bars). The intake length is 6 meters, and the area of the unit is $6 \mathrm{~m}^{2}$.

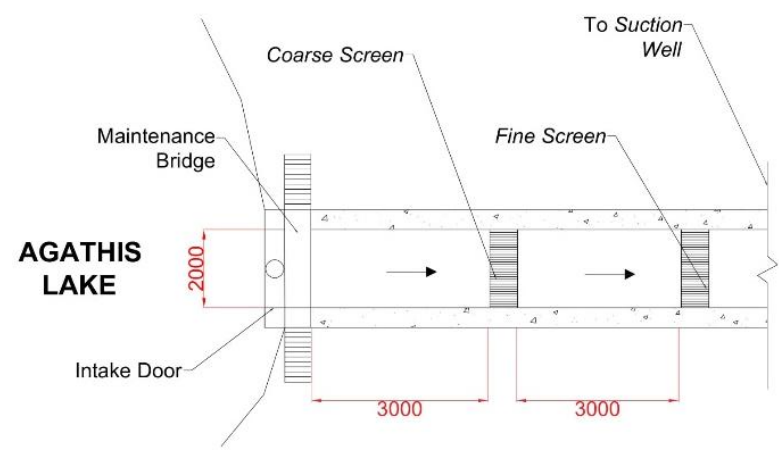

Fig 3. Top view of the intake unit (units in millimeters) (source: author's analysis, 2020) 


\section{Suction Well}

Two suction well units were designed with a length of 2,6 meters, a width of 1,7 meters, and an area of 5,6 $\mathrm{m}^{2}$ for each well. In each well, there is a centrifugal type suction pump with pumping power of $0,28 \mathrm{~kW}$ each.

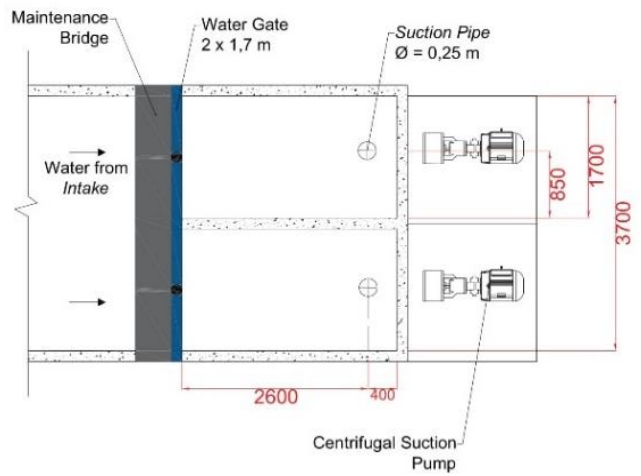

Fig 4. Top View of the Suction Well (units in millimeters).

\section{Transmission}

The transmission pipe is designed to be made of cast-iron with a length of 44,8 meters, a slope of 0,067 , and a pipe diameter of $25 \mathrm{~cm}$.

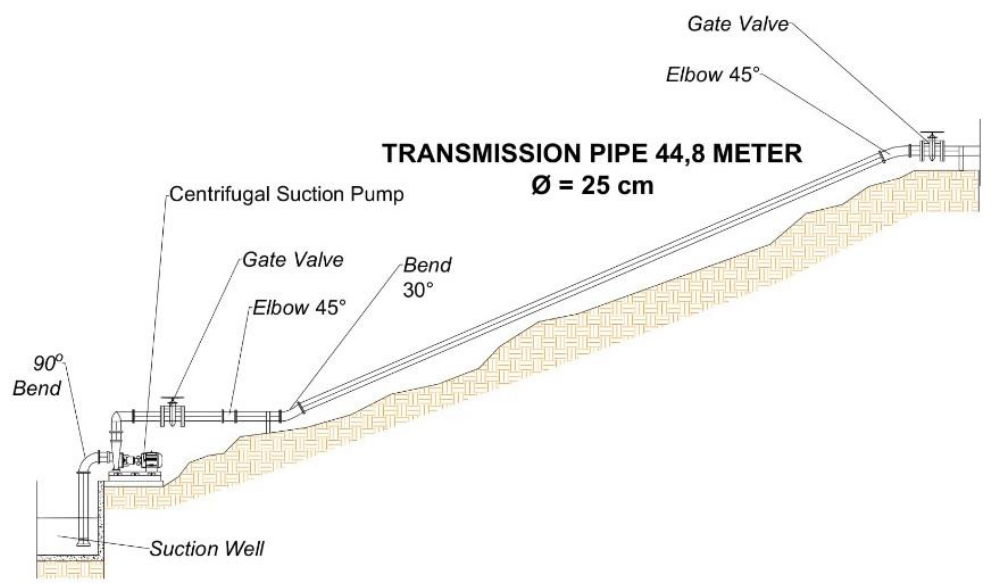

Fig 5. Side view of the Transmission Duct.

\section{Venturimeter Debit Measurement Tool}

The venturi meter is designed to have an overall length of $260 \mathrm{~cm}$, a throat length of $20 \mathrm{~cm}$, a throat diameter of $20 \mathrm{~cm}$, an entrance length of $50 \mathrm{~cm}$, pressure hole diameters of $2,5 \mathrm{~cm}$, a conical section length of $135 \mathrm{~cm}$, and a divergent outlet section length of $40 \mathrm{~cm}$. 


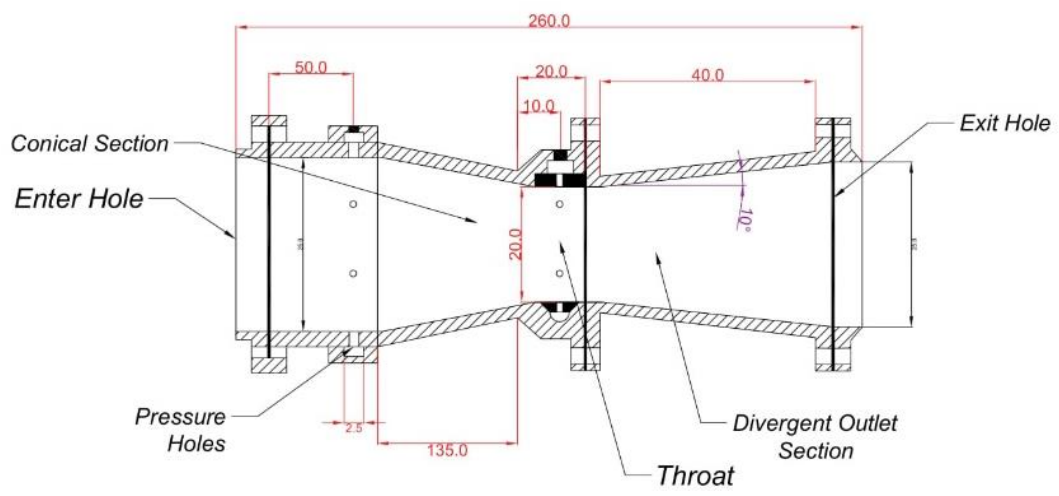

Fig 6. Section detail of the Venturimeter (units in millimeters).

\section{Slow Sand Filter}

Two slow sand filter units were designed, with each unit having a length of 8 meters, a width of 4 meters, and an area of $32 \mathrm{~m}^{2}$. The filtration rate of the filter is $0,2 \mathrm{~m} / \mathrm{hr}$. The media used were $60 \mathrm{~cm}$ thick silica sand and $40 \mathrm{~cm}$ thick GAC. Adjacent to the filter tank, there is a 2meter-long valve tank and a 4-meter-long outlet tank.

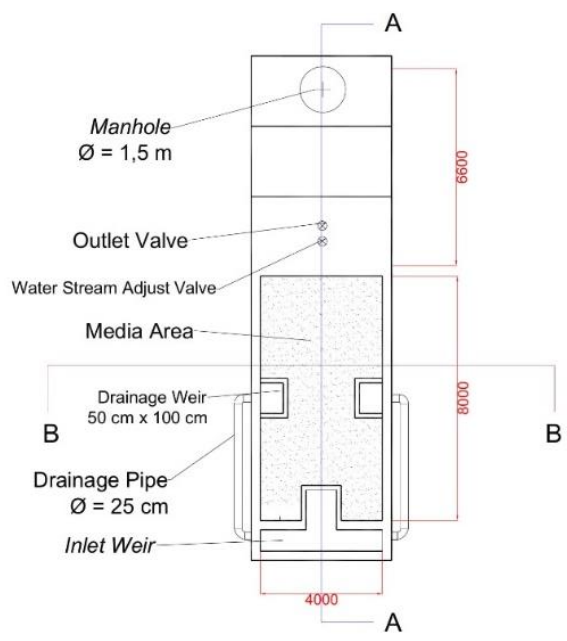

Fig 7. Top View of the Tank of the Slow Sand Filter (units in millimeters).

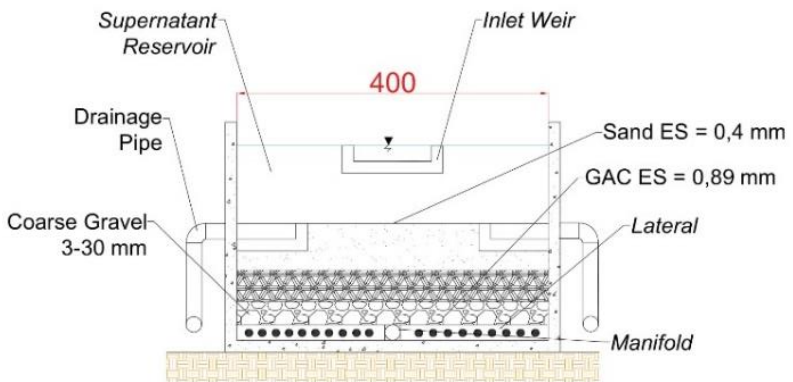

Fig 8. B-B Section Cut of the Tank of the Slow Sand Filter (units in centimeters). 


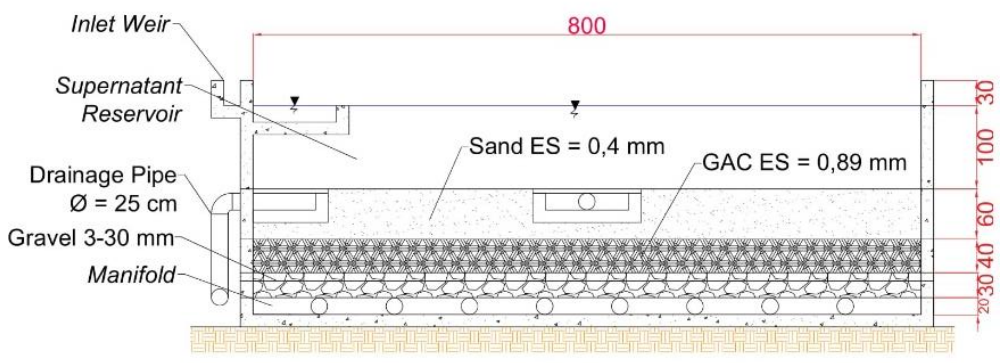

Fig 9. A-A Section Cut of the Tank of the Slow Sand Filter (units in centimeters).

\section{Disinfection Tank and Reservoir}

One unit of disinfection tank and one unit of the reservoir is designed. The disinfection tank is 1,2 meters wide and 2,4 meters long, with eight bulkheads where the tank flows vertically. The reservoir has a side length of 6,5 meters and a depth of 2,3 meters. Adjacent to the reservoir, four wet wells measure 2,5 meters x 1,5 meters with a depth of 2,5 meters. Above each wet well, there is a $0.13 \mathrm{~kW}$ pump that will transport ready-to-consume water from the well to FIK UI.

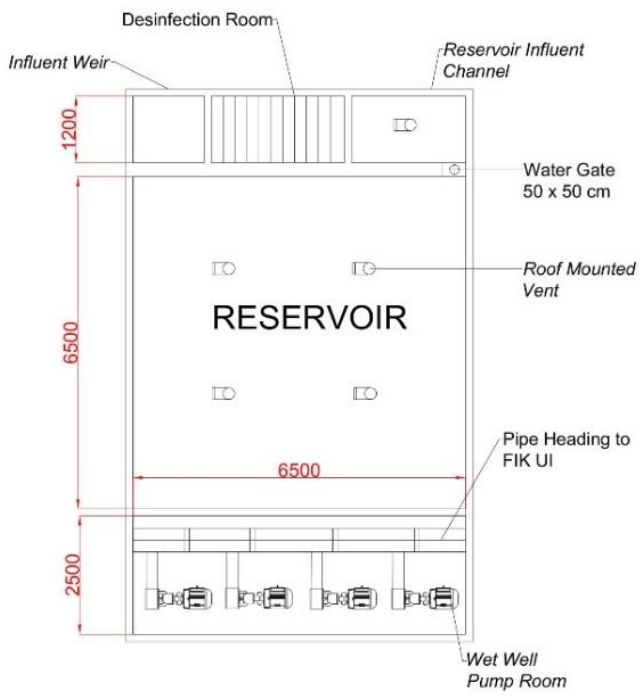

Fig 10. Top View of the Disinfection Tank and the Reservoir (units in millimeters). 


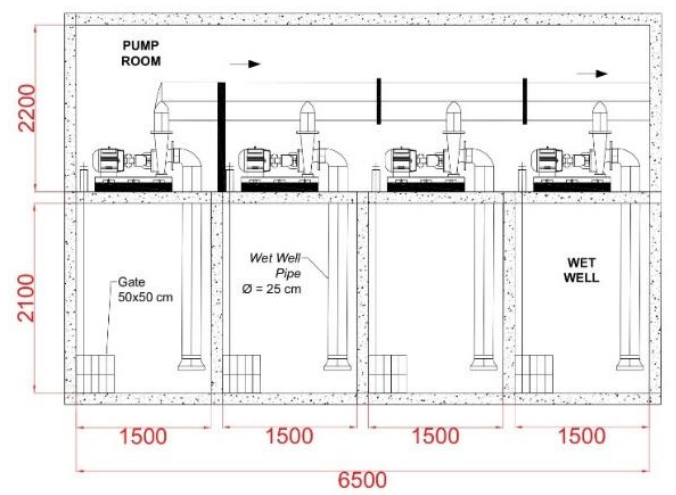

Fig 11. Wet Well Details (units in millimeters).

7. Filter Media Washing and Activation Unit

The washing unit is built to clean the filter media, namely silica sand and GAC, to overcome clogging. The activation unit is used for the reactivation of carbon in GAC after it is washed. The washing unit consists of a water and media mixing bath, washing tank, and media drying bath. Two filter media washing units are designed with an area of $28 \mathrm{~m}^{2}$ each. As for the activation chamber, one unit with a length of 3,6 meters and a width of 5,6 meters is made.

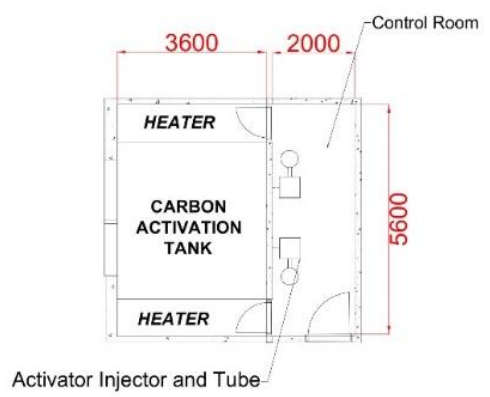

Fig 12. Details of the GAC Carbon Activation Room (units in millimeters).

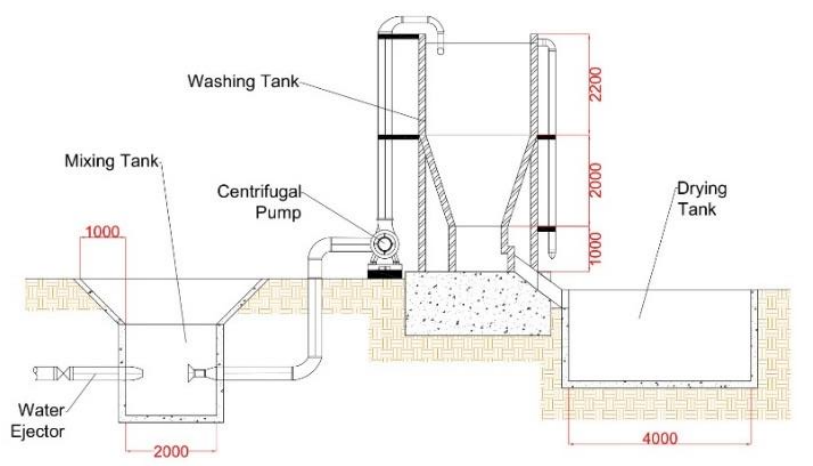

Fig 13. Details of the Filter Media Washing Unit (units in millimeters). 


\subsection{Layout of the WTP}

In each WTP unit, utility rooms such as laboratories, staff rooms, offices, employee toilets, etc. will be added so that the WTP can operate properly, and the comfort of employees who work at the WTP can be ensured. The details of the number of utility rooms for each WTP unit are as follows:

- Intake and suction well contain two staff rooms, one storage room, one security room, one small laboratory, two pump control rooms, and two restrooms.

- Slow sand filter contains two truck garages, one meeting room, one office room, one staff room, one storage room, one small laboratory, two restrooms, and one security room

- Disinfection and reservoir contains one control and disinfectant injection room, one small laboratory, one staff room, and one restroom

- Filter media washing unit contains one staff room, one storage room, one restroom, parking area, GAC activation control room, smoking area, and one security room.

In total, the required area for the WTP including all the utility rooms is $2112,89 \mathrm{~m}^{2}$.

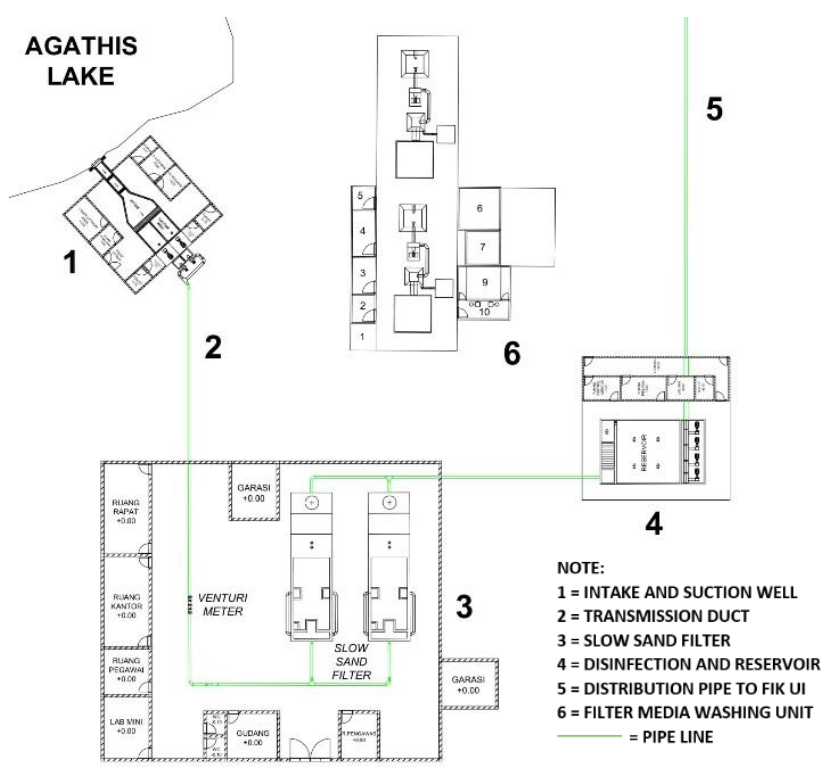

Fig 14. Layout Plan of the Overall WTP Complex.

\section{Conclusion}

1. Based on the projection results, the total need for clean water for the FIK UI community from 2022 to 2042 is $1,63 \mathrm{~L} / \mathrm{s}$ to $2,82 \mathrm{~L} / \mathrm{s}$. The design discharge obtained is based on the calculation of the maximum daily discharge and design discharge according to Qasim et al. [21] to serve FIK UI in 2022-2042 is $2,15 \mathrm{~L} / \mathrm{s}$ to $3,8 \mathrm{~L} / \mathrm{s}$.

2. Based on the review of literature, journals, and experiments conducted by other researchers, a slow sand filter with a thickness of about $60 \mathrm{~cm}$ for the silica sand layer (top) and $40 \mathrm{~cm}$ for the granular activated carbon layer (under the silica sand layer) can achieve a removal efficiency of iron and manganese parameters of 95,07\% and 97,09\% respectively [9], and fecal coliform parameters of $99 \%$.

3. The design of the WTP for serving FIK UI from 2022 to 2042 is as follows. 
- One intake unit with a length of 6 meters, a depth of 2 meters, and a width of 1 meter, equipped with a coarse screen and fine screen.

- Two suction well units with a length of 3 meters, a width of 1,7 meters, and a depth of 2 meters.

- One unit of transmission pipeline with a diameter of $25 \mathrm{~cm}$ and a length of 44,8 meters, which has increased by 3 meters, and is driven by a $0,28-\mathrm{kW}$ centrifugal pump.

- One unit for measuring the main discharge before entering the venturimeter type filtration unit.

- Two slow sand filter units with a filtration tank length of 8 meters and width of 4 meters.

- One unit of disinfection contact tank with a total length and width of the unit of 4,5 meters (plus the reservoir inlet channel) and 1,2 meters, with the reservoir unit's total length and width (plus wet well) being $9 \mathrm{~m}$ and 6,5 meters respectively.

- Two filter media washing units are consisting of a $2 \mathrm{~m} \times 2 \mathrm{~m}$ mixing bath, a $2 \mathrm{~m} \times 2$ $\mathrm{m}$ washing tank, a $4 \mathrm{~m} \mathrm{x} 4 \mathrm{~m}$ drying tank, a $2 \mathrm{~m} \times 2 \mathrm{~m}$ washing residue water tank, a 4,5 m x 4,5 m temporary silica sand containment tank, a 3,6 m x 3,6 m GAC containment tank, and a 3,6 m x 5,6 m GAC carbon activation chamber.

- An addition of utility rooms in the intake-suction right unit, slow sand filter, disinfection-reservoir, and filter media washing with the required total land area of $2112,89 \mathrm{~m}^{2}$.

\section{Acknowledgement}

We would like to thank to. Faculty of Nursing Universitas Indonesia's Head of Facility for giving important informations and allowing us to make the faculty as our focus object for this paper. This paper funded by PUTI Proceedings research grant.

\section{References}

1. Engineering Lab of University of Indonesia, Laporan Final Rencana Induk Sistem Penyediaan Air Minum Kampus Depok Universitas Indonesia, Depok: Engineering Lab of University of Indonesia (2019)

2. Said, Jurnal Ilmiah Teknik Lingkungan, Makassar: Hasanuddin University (1999)

3. C.R. Schulz \& Okun, D. A. Surface Water Treatment for Communities in Developing Countries. New York: John Wiley \& Sons, Inc (1984)

4. D. Maryani, Masduqi, A., \& Moesriati, A, Pengaruh Ketebalan Media dan Rate Filtrasi pada Sand Filter dalam Menurunkan Kekeruhan dan Total Koliform, Engineering Journal POMITS, 3, 2337-3539 (2014)

DOI: $10.12962 / \mathrm{j} 23373539 . v 3 i 2.6906$

5. A. R. Ramadhanis, Analisis Efektivitas Intermittent Slow Sand Filter dengan Tambahan Media Karbon Aktif dalam Menghilangkan Kandung Besi, Mangan, Kekeruhan, dan Fekal Koliform (Studi Kasus: Danau Mahoni UI), Depok: Environmental Engineering Major's Final Project in Universitas Indonesia (2019)

6. M.H. Al-Mughalles ,Rahman, R. A., Suja, F., Mahmud, M., \& Syed Abdullah, S. N., Greywater Treatment Using GAC Biofilm Reactor and Sand Filter System, Semantic Scholar: Journal of Applied Sciences Research, 8, 5237-5242 (2012) https://doi.org/10.1080/19443994.2013.813007

7. U. Jenti \& Nurhayati I., Pengaruh Penggunaan Media Filtrasi Terhadap Kualitas Air Sumur Gali di Kelurahan Tambak Rejo Waru Kabupaten Sidoarjo. Engineering Journal WAKTU, 12, 2 (2014) 
8. Mugiyantoro A., Rekinagara, I. H., Primaristi, C. D., \& Soesilo, J, Penggunaan Bahan Alam Zeolit, Pasir Silika, dan Arang Aktif dengan Kombinasi Teknik Shower dalam Filterisasi Fe, Mn, dan Mg pada Air Tanah di UPN Veteran Yogyakarta, Proceeding in the $10^{\text {th }}$ National Earth Seminar: Yogyakarta (2017)

9. Panigoro, S. A., Saraswati, D., \& Prasetya, E. 2015. "Pengaruh Variasi Ketebalan Pasir dan Karbon Aktif pada Media Saringan Pasir Lambat Terhadap Penurunan Kadar Besi dan Mangan pada Air Sumur". Gorontalo: Final Project of Public Health Major Universitas Negeri Gorontalo (2015)

10. Abdul H.N., Ahmad P.M.T., and Hafizhul K.,Pengaruh Aerasi Bertingkat dengan Kombinasi Saringan pasir, Karbon Aktif dan Zeolit dalam Menyisihkan Parameter Fe dan Mn dari Air Tanah di Pesantren Ar-Raudhatul Hasanah, Jurnal Dampak, 14, 1 (2017) DOI: https://doi.org/10.25077/dampak.14.1.1-12.2017

11. Hamidah L. N., \& Rahmayanti, A, Pemanfaatan Zeolit dan Karbon Aktif dalam Menurunkan Jumlah Bakteri pada Filter Pengolah Air Payau", Conference Proceeding on Waste Treatment Technology: Program Studi D4 Teknik Pengolahan Limbah Politeknik Perkapalan Negeri Surabaya (2018)

12. Putriani Elystia, S., \& Sasmita A., Pengaruh Tinggi Unggun Karbon Aktif dan Pasir Kuarsa Pada Saringan Pasir Lambat Untuk Penyisihan Logam Fe Pada Air Sungai Siak, Jom FTEKNIK, 6 (2019)

13. M. Spiegel \& Stephens, L., Schaum's Outline of Statistics, New York: McGraw Hill Professional (2007)

14. Indonesia's Directorate General of Human Settlements, Buku Panduan Pengembangan Air Minum", South Jakarta: Directorate General of Human Settlements (2007)

15. Indonesia's Research and Development Division of Ministry of Public Works, Spesifikasi Unit Paket Instalasi Pengolahan Air, Bandung: PUSKIM (2014)

16. MIWR-GONU, Technical Guidelines for the Construction and Management of Slow Sand Filters, Sudan: WHO and UNICEF Public Water Corporation (2009)

17. EPA, Water Treatment Manuals filtration, Ireland: Environmental Protection Agency (1995)

18. Indonesia's Research and Development Division of Ministry of Public Works, Modul Sosialisasi dan Diseminasi Standar Pedoman dan Manual dari Instalasi Saringan Pasir Lambat, Bandung: PUSKIM (2014)

19. S. Randtke \& M. Horsley, Water Treatment Plant Design 5th Edition, New York: McGraw Hill (2012)

20. M.L. Davis, Water and Wastewater Engineering, New York: McGraw Hill Companies Incorporated (2010)

21. S. R Qasim, Motley, E. M., \& Zhu, G. Water Works Engineering: Planning, Design, and Operation, New Jersey: Prentice Hall (2000) 